\title{
Damage costs due to bedload transport processes in Switzerland
}

\author{
A. Badoux ${ }^{1}$, N. Andres ${ }^{1}$, and J. M. Turowski ${ }^{2,1}$ \\ ${ }^{1}$ Swiss Federal Research Institute WSL, Zürcherstrasse 111, 8903 Birmensdorf, Switzerland \\ ${ }^{2}$ Helmholtz Centre Potsdam, GFZ German Research Centre for Geosciences, Telegrafenberg, 14473 Potsdam, Germany
}

Correspondence to: A. Badoux (badoux@wsl.ch)

Received: 19 July 2013 - Published in Nat. Hazards Earth Syst. Sci. Discuss.: 22 August 2013

Revised: 4 December 2013 - Accepted: 29 December 2013 - Published: 18 February 2014

\begin{abstract}
In Alpine regions, floods are often associated with erosion, transport and deposition of coarse sediment along the streams. These processes are related to bedload transport and pose a hazard in addition to the elevated water discharge. However, it is unclear to what extent they contribute to total damage caused by natural hazards. Using the Swiss flood and landslide damage database - which collects financial damage data of naturally triggered floods, debris flows and landslides - we estimated the contribution of fluvial bedload transport processes to total damage costs in Switzerland. For each database entry an upper and lower limit of financial losses caused by or related to bedload transport processes was estimated, and the quality of the estimate was judged. When compared to total damage, the fraction of bedload transport damage in the $40 \mathrm{yr}$ study period lies between 0.32 and 0.37 . However, this value is highly variable for individual years (from 0.02 to 0.72 ). Bedload transport processes have induced cumulative financial losses between CHF 4.3 and 5.1 billion. Spatial analysis revealed a considerable heterogeneous distribution with largest damage for mountainous regions. The analysis of the seasonal distribution shows that more than $75 \%$ of the bedload damage costs occurs in summer (June-August), and $\sim 23 \%$ in autumn (SeptemberNovember). With roughly $56 \%$, by far most of the damage has been registered in August. Bedload transport processes are presently still inadequately understood, and the predictive quality of common bedload equations is often poor. Our analysis demonstrates the importance of bedload transport as a natural hazard and financial source of risk, and thus the need for future structured research on transport processes in steep streams.
\end{abstract}

\section{Introduction}

Worldwide, natural hazard events such as floods and landslides cause large financial damage every year. Most recently, MunichRe $(2012,2013)$ reported worldwide overall losses of USD 380 and 170 billion for natural catastrophes in 2011 and 2012, respectively. Osterkamp et al. (1998) estimated that physical, chemical and biological damage due to movement and deposition of fluvial sediment in North America exceeded USD 16 billion per year (base of 1992 dollars). Their estimates are based on literature addressing environmental and economic damage costs by fluvial erosion, sediment transport and re-deposition of material and sorbed contaminants. In Alpine regions, floods in torrents and steep mountain streams are almost always associated with sediment transport in the form of debris flows and fluvial bedload transport. A stream may transport bedload without inducing major changes to the channel as long as the quantity of bedload entering a reach is equal to that exiting. However, if input and output are not balanced, large flood events can lead to overbank sedimentation and deposition on alluvial fans, for example as a result of a rapid decrease in channel gradient along critical reaches (e.g. Jäggi et al., 2004). Especially where mountain streams draining large catchments $(>10$ $20 \mathrm{~km}^{2}$ ) meet densely populated areas and infrastructure, the damage potential is considerable (Bezzola et al., 1994; White et al., 1997; Arnaud-Fassetta et al., 2005; Bezzola and Hegg, 2007; Totschnig et al., 2011). In addition, lateral erosion along stream banks often causes substantial financial damage during large floods (e.g. Waananen et al., 1971; Balog, 1978; Walther et al., 2004; Hunzinger and Durrer, 2008; Krapesch et al., 2011), sweeping away agricultural land, destroying roads and other infrastructure, and damaging buildings. Thus, bedload transport represents a principal natural 
hazard in a mountainous environment (e.g. Rickenmann and Koschni, 2010). The assessment of damage costs over large spatial and temporal scales is important and provides a sound basis for the evaluation and definition of protection requirements of a national economy. It adds to the European flood risk directive of October 2007 (2007/60/EC) in delimiting areas of bedload process activity in the vicinity of rivers and river banks, thus supporting zoning and planning. Furthermore, fluvial erosion and deposition damage estimates could be helpful in assessing the degree of efficiency of existing protection measures. Nitsche et al. (2011) estimated that bedload transport processes contributed a third to a half of the total financial damage in the severe August 2005 flood event in Switzerland, amounting to up to CHF 1.5 billion. Nevertheless, we suspect that the importance of bedload transport processes is generally underestimated in a regional or national perspective.

Data on damage caused by floods, debris flows, and landslides have been systematically collected in Switzerland since 1972, and rockfall data since 2002. Information on natural hazard events affecting property values, infrastructure, forestry and agriculture is described and recorded in the Swiss flood and landslide damage database (Hilker et al., 2009). On average, damage costs amount to about CHF 330 million a year for the period from 1972 to 2011 (Andres et al., 2013). At approximately CHF 90 million the median value is considerably lower, which points to the significance of a few major events during this time. Database entries are assigned to one of three main categories. The vast majority of the costs $(93.3 \%)$ can be ascribed to flooding in the broad sense, including debris flows. The remaining costs are split between landsliding $(6.4 \%)$ and rockfall $(0.3 \%)$. Of course, the quite coarse classification cannot comply with the multiplicity of potential natural hazard processes in Alpine regions. In particular, the category "flood/debris flow" does not differentiate between the actual flooding or inundation process by small streams, rivers or lakes and the erosion and deposition of material along a water channel. However, in general the provided information allows determining whether and to what extent fluvial erosion or deposition took place.

To the knowledge of the present authors the quantification of financial damage induced by fluvial erosion and deposition of bedload in steep streams and in rivers has never been systematically undertaken. Here, we present a re-analysis of the Swiss flood and landslide damage database quantifying the fraction of financial losses related to bedload transport processes over a study period of $40 \mathrm{yr}$ along water courses in Switzerland. As such, our study represents the first analysis of the spatial distribution of financial losses caused by bedload transport. The observed distribution is discussed by relating regional cost estimates to simple parameters describing the geomorphic characteristics of defined subareas.

\section{Data and methods}

\subsection{Data on damage caused by natural hazards in Switzerland}

Since 1972, estimates of the direct financial damage caused by naturally triggered floods, debris flows, landslides and (since 2002) rockfall events have been collected in the Swiss flood and landslide damage database (Hilker et al., 2009). The project is ongoing and at the time of writing the database comprises $40 \mathrm{yr}$ of data. It represents the basis of the present study focussing on damage costs related to fluvial bedload transport processes. The structure of the Swiss flood and landslide damage database and the process of estimating financial damage are described in detail by Hilker et al. (2009). Here, we briefly recapitulate the most important aspects of the database and then describe the assessment of damage related to bedload transport.

The main source of information for the damage data is provided by approximately 3000 Swiss newspapers and magazines, scanned daily by a media-monitoring company. Additional information may be collected from insurance companies, public authorities and police or fire brigade websites.

For each community affected by a single natural hazard damage event, a data set entry is generated. A data set contains information on (i) the locality where damage was caused, (ii) date and time, (iii) the type of damage-causing process and secondary processes, (iv) the triggering weather conditions, (v) a description of the event, (vi) the number of fatalities, and (vii) the estimated direct cost of damage in the community. In some cases, damage cannot distinctively be assigned to a municipality; therefore the damage event is allocated to the affected canton. In one case where financial damage could not be assigned to a canton, a data set entry for the entire country was created.

A data set entry describing a specific event is allocated to one of the main damage process categories: flood/debris flow, landslide or rockfall. In this study we are interested in the category flood/debris flow, which includes the actual flooding processes by small streams, rivers or lakes (inundation) as well as erosion and deposition of material along a water channel. In many cases additional information is provided in the database, and secondary processes (such as overbank sedimentation and bank erosion) are indicated. The availability of such supplementary information depends on the detail and accuracy of the data source.

The direct financial damage in CHF is estimated according to the information sources, whereby the estimates are largely based on experience. Costs are associated with a certain type of affected object (Table 1 of Hilker et al., 2009). These object types are subdivided into three main classes: (i) "material assets" such as destroyed or damaged buildings, protection structures, vehicles, etc.; (ii) "traffic lines/infrastructure" such as transportation routes, powersupply and telephone lines; and (iii) "forestry/agricultural 
land". While insured property damage costs and not-insured or not-insurable material damage costs (i.e. direct financial damage) are considered in the Swiss flood and landslide damage database, indirect losses, later reconstruction measures and intangible damage are not included. We provide damage costs in CHF in our contribution (value as on 15 July 2013: CHF $1=$ EUR $0.81=$ USD 1.05) and take inflation into account for all financial data.

\subsection{Estimation of damage caused by bedload transport processes}

A river carries sediment in two different ways (Einstein, 1950; Vanoni, 1975): (i) as bedload when particles roll, slide or saltate along the channel bed or (ii) as suspended load when particles are supported by turbulent forces and move considerable distances without touching the channel bed. Whether a particle of a certain size is transported in the form of bedload or suspended load depends on the hydraulic characteristics of a channel. Generally, with increasing catchment size and decreasing channel gradient, the threshold particle size for bedload transport decreases (e.g. Bathurst et al., 1987; Lamb et al., 2008). In the context of this contribution, we consider sand and coarser size fractions. We did not consider damage costs due to debris flows (e.g. Costa, 1984).

The Swiss flood and landslide damage database includes 19013 single entries for the period from 1972 to 2011. Running a search for 22 specific keywords (see Supplement, Table S1) related to fluvial bedload transport and channel erosion, we were able to reduce our working database to 5517 entries in a first step. All these entries had to be screened separately in a second step. During this process, for each entry we had to decide whether bedload deposition or sediment erosion played any role in the damage symptoms or not. As a result of this, our working database was further reduced to 3588 entries (the 1929 entries that were dismissed were mostly related to debris flows, as well as landslides and lowland floods). The financial damage induced by bedload transport processes was then estimated for each remaining entry (see fictitious example in Supplement, Fig. S1). For the estimation procedure, we decided to apply an upper and a lower limit of damage for every object type within an entry, because it was often difficult to determine a single sharp value. We treated each object type identically, interpreting the written information and converting it into damage figures. The better the event was described and defined, the tighter we were able to keep the range of our estimation. This range between the lower and upper bedload damage estimates thus represents an appraisal of the degree of confidence regarding the amount of bedload damage (by contrast with the reliability regarding the damage cause as described below).

In some cases, it was difficult to identify the exact natural hazard processes responsible for damage within a single entry. For example, large woody debris in combina- tion with channel aggradation can play an important role in bridge clogging under high flow conditions that regularly causes considerable damage. These wood particles originate e.g. from landslides, the lateral erosion of vegetated banks or deadwood lying in the streams before discharge events. Such situations occurred during the severe August 2005 flood event in the catchments of the Grosse Melchaa and the Landquart, causing inundations and the deposition of coarse material and wood particles in Sarnen (canton Obwalden) and Klosters (canton Grisons), respectively (Bezzola and Hegg, 2008; cf. Sect. 3.3). However, the information provided in the Swiss flood and landslide damage database is generally not detailed enough to allow for an exhaustive analysis of the influence of wood in bedload transport events. This applies particularly for small- and medium-sized events. Also, the differentiation between the processes of fluvial bedload transport and debris flows can be complicated. We generally relied on the event description within the original Swiss flood and landslide damage database that is based on newspaper articles. Yet, because media articles sometimes mix up technical terms, we partly used photo coverage (e.g. of depositional pattern) and maps to pinpoint correct processes in our re-evaluation of the database. Furthermore, expert knowledge and/or local knowledge were consulted if necessary.

In addition, we introduced a possibility to assess the uncertainty regarding the described damage process. In the Swiss flood and landslide damage database, costs are associated with a certain type of affected object (see above and Hilker et al., 2009). For every existent estimate in a certain object type for which bedload deposition or sediment erosion is held responsible, the reliability in terms of the underlying damage process can be evaluated. This is carried out by assigning to the estimate pair (lower and upper limits) a number from 1 to 3 , termed process uncertainty index, where 1 indicates high reliability regarding damage cause and 3 indicates poor reliability regarding damage cause. For each entry a mean process uncertainty index is calculated by weighting the factors associated with the different cost estimates based on the absolute value of the estimate. Similarly, mean process uncertainties for entire damage events or years in the investigation period can be assessed.

Finally, we have provided the possibility to specify every estimate pair associated with any object type and ascribed to sediment erosion or bedload deposition as "bedload-related damage" specifically. We define bedload-related damage as any damage that occurs because considerable bedload processes made it possible. An example is damage caused by flood water after channel aggradation occurred on an alluvial fan. In this case the damage was made possible by a bedloadrelated process (channel aggradation), even though bedload was not directly responsible for it. 
Table 1. Characteristics of the seven Swiss subareas applied in this contribution (cf. Fig. 1).

\begin{tabular}{|c|c|c|c|c|c|c|c|c|c|c|}
\hline \multirow[t]{2}{*}{ No. } & \multirow[t]{2}{*}{$\begin{array}{l}\text { Subarea } \\
\text { name }\end{array}$} & \multirow{2}{*}{$\begin{array}{l}\text { Size } \\
{\left[\mathrm{km}^{2}\right]}\end{array}$} & \multirow{2}{*}{$\begin{array}{r}\text { Population }^{\mathrm{a}} \\
\text { [1000] }\end{array}$} & \multirow{2}{*}{$\begin{array}{r}\text { Mean } \\
\text { elevation } \\
\text { [ma.s.l.] }\end{array}$} & \multirow{2}{*}{$\begin{array}{l}\text { Mean annual } \\
\text { precipitation }^{\mathrm{b}} \\
{[\mathrm{mm}]}\end{array}$} & \multicolumn{3}{|c|}{$\begin{array}{c}\text { Number of } \\
\text { municipalities }^{c}\end{array}$} & \multirow{2}{*}{$\begin{array}{r}\text { Bedload damage } \\
\text { per person and year } \\
{\left[\mathrm{CHF}^{\mathrm{d}} \mathrm{cap}^{-1} \mathrm{a}^{-1}\right]}\end{array}$} & \multirow[t]{2}{*}{$\begin{array}{l}\text { Predominant } \\
\text { lithology } \mathrm{e}\end{array}$} \\
\hline & & & & & & total & affected & {$[\%]$} & & \\
\hline 1 & Jura & 4207 & 1018.6 & 804 & 1307 & 417 & 109 & 26 & 0.83 & massive limestones \\
\hline 2 & Swiss Plateau & 11016 & 4938.2 & 560 & 1151 & 1271 & 420 & 33 & 1.26 & $\begin{array}{l}\text { quaternary deposits; } \\
\text { marl formations }\end{array}$ \\
\hline 3 & Prealps & 4673 & 840.3 & 1007 & 1587 & 237 & 170 & 72 & 19.3 & $\begin{array}{l}\text { quaternary deposits; conglomerates; } \\
\text { massive limestones; slates and schists }\end{array}$ \\
\hline 4 & Central Alps & 6669 & 364.1 & 1639 & 1689 & 132 & 119 & 90 & 229.3 & $\begin{array}{l}\text { massive limestone; slates and schists; } \\
\text { quaternary deposits }\end{array}$ \\
\hline 5 & Valais & 4798 & 264.4 & 2199 & 1308 & 124 & 109 & 88 & 215.1 & $\begin{array}{l}\text { sericite-chlorite gneiss and slates; } \\
\text { quaternary deposits }\end{array}$ \\
\hline 6 & Ticino & 3252 & 344.9 & 1424 & 1803 & 174 & 100 & 57 & 222.6 & mica and biotite gneiss \\
\hline 7 & Grisons & 6619 & 184.2 & 2044 & 1192 & 160 & 87 & 54 & 25.9 & $\begin{array}{l}\text { mica and biotite gneiss; } \\
\text { quaternary deposits; limestones }\end{array}$ \\
\hline
\end{tabular}

a According to the Swiss Federal Statistical Office for the year 2011.

b Data source: MeteoSwiss (1961-2011).

c As of end of 2011; the number of affected municipalities denotes municipalities with at least one entry reporting bedload transport damage.

$\mathrm{d}$ This value represents the mean of all municipalities (affected or not) for a given subarea.

e According to the Geotechnical Map of Switzerland (BFS GEOSTAT/BUWAL).

\subsection{Spatial presentation of the data}

We used two spatial resolutions in this study to represent the distribution and variability of damage costs induced by bedload transport processes. In the damage database the data are acquired at municipal level. In Switzerland there are 2495 political municipalities (as of 1 January 2012), comprising areas ranging from 0.32 to $430 \mathrm{~km}^{2}$. Municipal data were furthermore combined into seven regions based on geomorphologic-climatic criteria (Fig. 1). Our approach rests on a subdivision used in avalanche warning by the WSL Institute for Snow and Avalanche Research SLF (2012). A total of 124 SLF warning regions were combined to form seven subareas that vary in elevation range, gradient and/or climatic influences: Jura, Swiss Plateau, Prealps, Central Alps, Valais, Grisons, and Ticino (Fig. 1). The main characteristics of the seven Swiss subareas are summarized in Table 1.

To investigate controls on damage costs caused by bedload deposition and sediment erosion, the straightforward method would have been to put damage estimates in relation to parameters acquired at the hydrological catchment level. However, the quality of the spatial information provided by the event entries of the Swiss flood and landslide damage database does not allow for the adoption of this approach. This is because, firstly, for many events included in this study, the basic information is not extensive enough to pinpoint a distinct centre of damage, or even the stream that was active in the event. In these cases only the affiliation of the bedload damage costs to a certain political municipality is practicable. Secondly, for better described events, the coordinates provided are referring to the location of the main damage occurred, which is not necessarily the site where sediment was eroded, mobilized and subsequently transported.

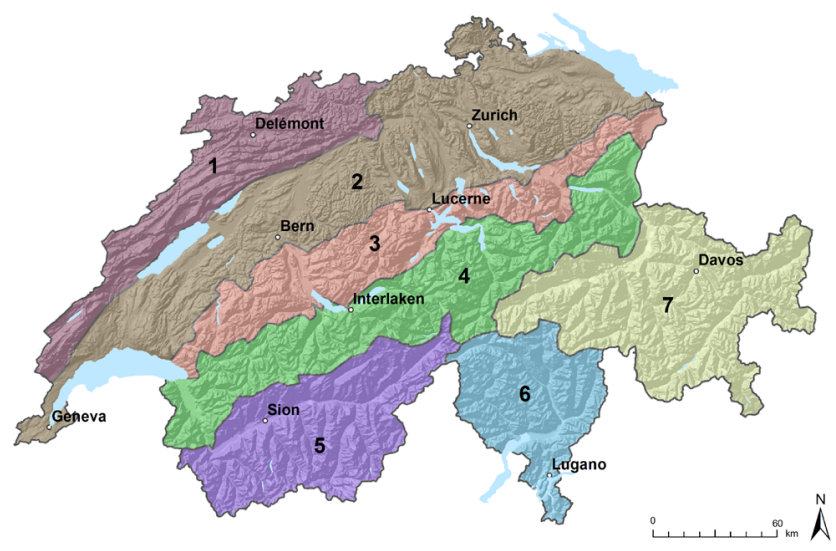

Fig. 1. Location of the seven subareas for which bedload damage data were aggregated according to Table 1 (1-Jura; $2-$ Swiss Plateau; 3 -Prealps; 4 -Central Alps; 5 -Valais; 6-Ticino; 7 -Grisons) displayed together with the digital elevation model of Switzerland (data: BFS GEOSTAT/Federal Office of Topography swisstopo). Note that these subareas do not necessarily correspond to cantonal boundries.

\subsection{Determination of topological parameters in subareas}

We characterized the physiographic properties of the municipalities and the seven subareas (cf. above) by the mean and standard deviation both of the absolute altitude and the channel bed gradient. These data were obtained from a digital elevation model with a spatial resolution of $10 \mathrm{~m} \times 10 \mathrm{~m}$. Channel bed gradients were calculated with standard flow routing algorithms for all grid cells defined as a stream cell, i.e. that drain a hydrological catchment with an area of at least $0.1 \mathrm{~km}^{2}$ (from this catchment size, hydrographic networks start to form). The choice of a threshold value of $0.1 \mathrm{~km}^{2}$ 
leads to high mean subarea/municipal gradients. However, note that the mean channel gradients derived here merely represent characteristic values for single municipalities or subareas and do not correspond to a channel slope in the upstream proximity of damage sites or to the average value of a hydrological catchment. Also, obtained mean channel gradients were not applied to differentiate between different natural hazard processes. In addition to the physiographic differentiation, the subareas and municipalities were characterized by the spatially averaged annual precipitation (cf. Table 1), the 1-day rainfall values with a recurrence interval of $100 \mathrm{yr}$ and the population density. Rainfall information was derived from the RhiresD data set (Wüest et al., 2010; Frei and Schär, 1998), which is based on daily precipitation totals measured at the rain-gauge network of MeteoSwiss and has a kilometre-scale grid point spacing.

\section{Results}

\subsection{Temporal distribution of bedload damage costs}

From 1972 to 2011, sediment erosion and bedload deposition has induced a cumulative financial damage between CHF 4.3 and 5.1 billion (Fig. 2), which is about one-third of the total damage. Approximately $73 \%$ of the cumulative damage costs caused by bedload transport processes affect the object types classified as "material assets" (e.g. destroyed or damaged buildings; cf. Sect. 2.1). One quarter of the damage costs is related to "traffic lines and infrastructure" and as little as $2 \%$ of the losses are attributed to damage on "forestry and agricultural land". Annual losses due to bedload transport, just like total annual losses caused by all the natural hazard processes considered in the Swiss flood and landslide damage database (Hilker et al., 2009), vary considerably from year to year. We specified roughly $12-13 \%$ of the cumulative bedload transport costs as bedload-related damage (CHF 550-630 million).

The average annual cost of damage caused by bedload transport processes in the $40 \mathrm{yr}$ study period lies between CHF 110 and 125 million (mean of yearly lower and upper estimates). The median value, however, is considerably lower (CHF 13-16 million), reflecting the high variability in the annual damage data (Fig. 2). In years with very high to exceptionally high total costs (>CHF 500 million), damage costs due to bedload transport often also exceed the mean annual value. The two exceptions to this pattern are 1999 and 2007, two years strongly influenced by considerable floods in large Swiss rivers, such as e.g. the Aare river, mainly affecting the Swiss Plateau. During the other years with high total damage costs, the occurred bedload transport damage can generally be ascribed to one major event and is not the result of several small or medium events (cf. Sect. 3.3).

Damage costs caused by bedload transport processes are fairly evenly distributed over the four decades covered by the

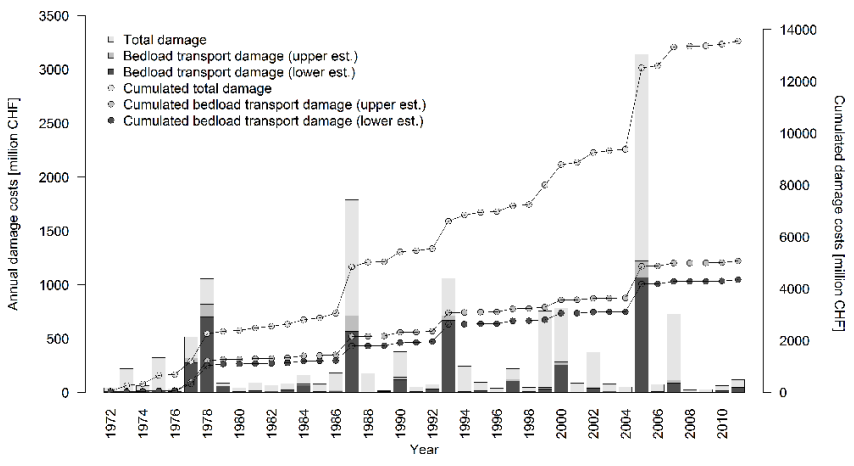

Fig. 2. Annual cost of damage caused by bedload transport processes in Switzerland from 1972 to 2011. While total bar length indicates the overall damage costs as recorded in the Swiss flood and landslide damage database (Hilker et al., 2009), the two darker grey tones give the lower and upper estimates for bedload transport damage costs. The different lines show cumulative costs for overall damage and damage due to bedload transport processes.

study (Fig. 2). This can be explained by the fact that at least one severe event, during which sediment transport played a crucial role, occurred in each of the decades. The upper estimates vary between CHF 1028 million for the decade from 1982 to 1991 and CHF 1496 million for the decade from 2002 to 2011, with a mean value of CHF 1266 million. Clusters of consecutive years with substantial bedload transport damage are rare. Three above-median years in a row are reported only once in the data set from 1977 to 1979 , showing a cumulated financial loss of approximately CHF 1200 million (upper estimates). Periods with very little damage costs induced by bedload transport are more frequent and occurred e.g. from 1972 to 1976 , from 1980 to 1986 and from 2001 to 2004 (all below-average years).

The fraction of bedload transport damage compared to the total damage lies between 0.32 and 0.37 for the full investigation period. However, this fraction was highly variable from year to year (Fig. 2). While very low values below 0.05 are reported for the years 1973, 1988, 1994, and 2001, our estimations resulted in fractions of approximately two-thirds or more for the years 1978, 1979, and 1993. For single severe flood events such as the Brig sediment disaster of 24 September 1993 (cf. below Sect. 3.3 and Bezzola et al., 1994) the value exceeded 0.80 . In contrast, the ratio of bedload damage costs to total costs does not vary considerably from decade to decade. The first decade of our data set (19721981) shows the highest value of 0.48 (ratio calculated using the mean of the lower and upper estimates). In the following three decades the ratios amount to $0.31,0.35$, and 0.30 , respectively.

The seasonal distribution of damage due to bedload processes follows the distribution of the total damage costs according to the flood and landslide database, but its nonuniformity is even more accentuated (Table 2). Nearly all of the damage due to bedload transport occurs in summer (June 
Table 2. Monthly distribution of the estimates of damage caused by bedload processes (cumulative data for the period 1972-2011).

\begin{tabular}{|c|c|c|c|c|c|c|c|}
\hline \multirow[t]{2}{*}{ Month } & \multicolumn{2}{|c|}{$\begin{array}{l}\text { Bedload damage } \\
\text { (lower est.) }\end{array}$} & \multicolumn{2}{|c|}{$\begin{array}{l}\text { Bedload damage } \\
\text { (upper est.) }\end{array}$} & \multirow{2}{*}{$\begin{array}{c}\begin{array}{c}\text { Total costs } \\
\text { of damage }\end{array} \\
{[\text { million } \mathrm{CHF}]}\end{array}$} & \multirow{2}{*}{$\begin{array}{c}\begin{array}{c}\text { Fraction bedload } \\
\text { damage/tot. } \\
\text { damage }^{b}\end{array} \\
{[-]}\end{array}$} & \multirow{2}{*}{$\begin{array}{c}\begin{array}{c}\text { Process } \\
\text { uncertainty } \\
\text { index }^{c}\end{array} \\
{[-]}\end{array}$} \\
\hline & [million CHF] & {$[\%]$} & [million CHF] & {$[\%]$} & & & \\
\hline January & 0.8 & $<0.1$ & 1.1 & $<0.1$ & 49.3 & 0.02 & 2.15 \\
\hline February & 17.7 & 0.4 & 26.4 & 0.5 & 239 & 0.09 & 2.55 \\
\hline March & 2.0 & $<0.1$ & 3.4 & $<0.1$ & 51.5 & 0.05 & 2.22 \\
\hline April & 3.5 & $<0.1$ & 4.9 & 0.1 & 84.8 & 0.05 & 1.90 \\
\hline May & 46.2 & 1.1 & 65.4 & 1.3 & 1018 & 0.05 & 2.00 \\
\hline June & 127 & 2.9 & 161 & 3.2 & 1173 & 0.12 & 1.52 \\
\hline July & 707 & 16.3 & 860 & 17.0 & 1991 & 0.39 & 1.87 \\
\hline August & 2415 & 55.6 & 2826 & 55.8 & 6609 & 0.40 & 1.91 \\
\hline September & 699 & 16.1 & 750 & 14.8 & 1180 & 0.61 & 1.27 \\
\hline October & 306 & 7.1 & 341 & 6.7 & 861 & 0.38 & 1.60 \\
\hline November & 16.5 & 0.4 & 23.5 & 0.5 & 234 & 0.09 & 2.32 \\
\hline December & 1.3 & $<0.1$ & 2.4 & $<0.1$ & 64.3 & 0.03 & 2.60 \\
\hline All year & 4342 & 100 & 5065 & 100 & 13555 & 0.35 & 1.78 \\
\hline
\end{tabular}

a According to the Swiss flood and landslide damage database.

${ }^{\mathrm{b}}$ For the calculation of the fraction of bedload damage costs to total damage costs, the mean value of the two estimates was applied.

${ }^{\mathrm{c}}$ The process uncertainty index given here applies for all bedload damage estimations within the given month (assessed using the upper damage estimates for weighting single database entries).

through August, $>75 \%$ ) or in autumn (September through November, ca. $23 \%$ ). With roughly $56 \%$, by far most of the damage has been registered in the month of August. Financial losses in winter and spring combine to about $2 \%$ of the total. As expected, the ratio of bedload transport damage to total damage falls in line with the absolute occurrence of bedload transport damage (Table 2). While the fraction lies below 0.10 from November to May, June represents a transition month with 0.11-0.14 (based on lower and upper estimates, respectively). In July, August, and October the ratio amounts to roughly 0.40, and in September it reaches a maximum value with approximately 0.60 , which can largely be ascribed to the Brig sediment disaster of 1993 mentioned above.

\subsection{Spatial distribution of bedload damage costs}

The spatial distribution of the cumulative damage costs caused by bedload deposition and sediment erosion in the $40 \mathrm{yr}$ from 1972 to 2011 is displayed at two different spatial resolutions: (a) at the municipal level (borders from 2011) according to the data acquisition in the Swiss flood and landslide damage database (Fig. 3), and (b) aggregated at the regional level (Fig. 4).

\subsubsection{Municipal level}

A high spatial variability in financial losses caused by bedload transport processes can be observed in Switzerland on the municipal level (Fig. 3). In general, medium and high cumulative costs are concentrated in mountainous regions (subareas 3-7). Only very few clusters of severely affected mu-

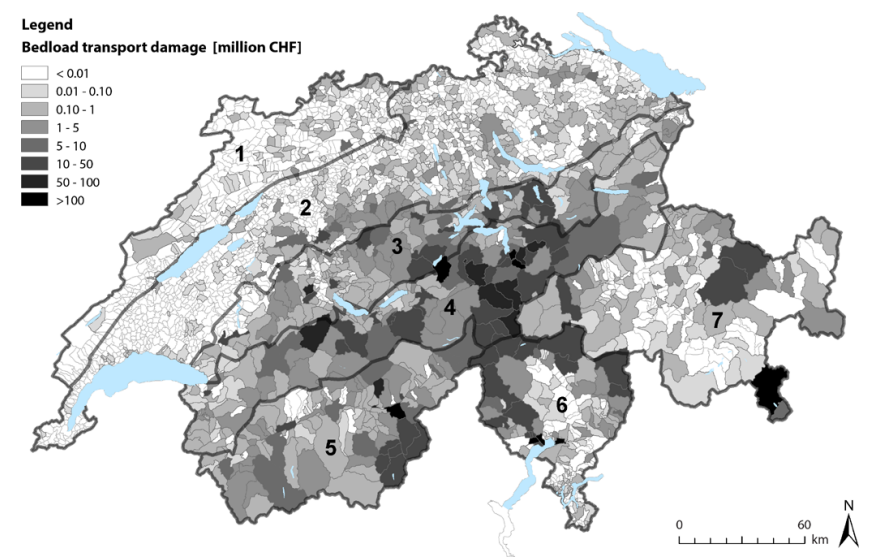

Fig. 3. Spatial distribution of damage costs caused by bedload processes over the entire $40 \mathrm{yr}$ study period at the municipal level (mean of the lower and upper estimates were applied). The bold black lines indicate the borders of the subareas (Fig. 1; Table 1). Note that CHF 460-535 million of losses could not distinctively be assigned to a single municipality.

nicipalities exist. Most communities with high cumulative bedload transport damage ( $>$ CHF 50 million, the top two classes in Fig. 3) are reported from the Central Alps (subarea no. 4; nine communities), followed by the Valais and Ticino (subareas no. 5 and 6, respectively; two communities each) and the Grisons and Prealps (subareas no. 7 and 3 , respectively; one community each). Mostly, the majority of reported damage costs in a municipality occurred during one large event. In communities of the lowland subarea 


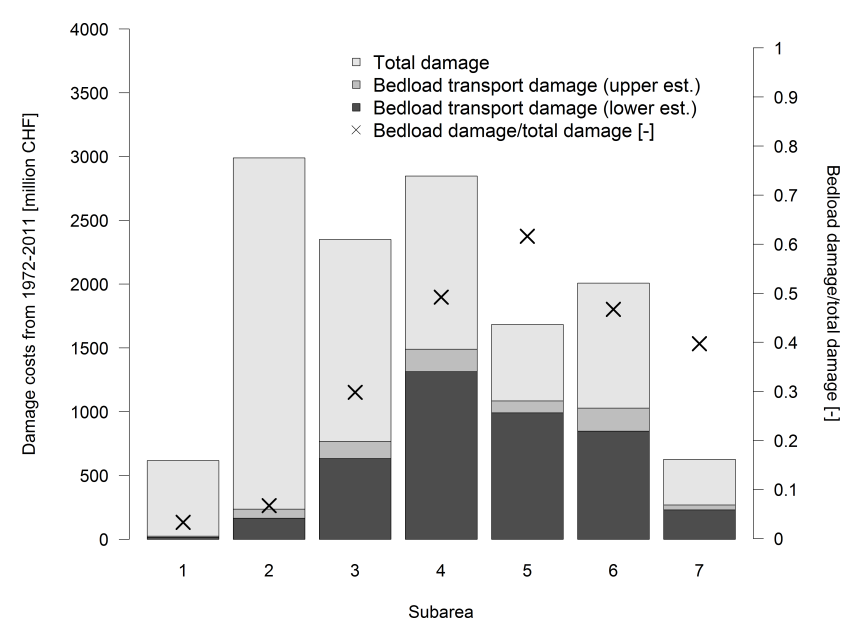

Fig. 4. Total damage costs and damage costs by bedload transport for the seven subareas (Fig. 1; Table 1) over the $40 \mathrm{yr}$ study period. Crosses indicate the ratio of costs caused by bedload transport processes (mean of the two estimates) to total costs. Note that CHF 145-165 million of losses could not distinctively be assigned to a subarea.

Swiss Plateau (no. 2) and of the hilly Jura subarea (no. 1), cumulative damage costs in the $40 \mathrm{yr}$ period do not exceed CHF 12 million, and only a few municipalities have encountered considerable problems due to bedload processes there. Actually, many municipalities all over Switzerland have been exposed to very little financial losses related to bedload transport (or none at all), most of which are located in the Swiss Plateau and Jura. To a lesser extent, such communities also arise in southeastern Switzerland in the subareas of Grisons and Ticino.

Within the Swiss Plateau, the northeastern and central parts of the subarea show more municipalities affected lightly or at a medium level than the southwestern part. In the latter part of the subarea, even lightly affected municipalities are scarce. Such heterogeneity within a subarea can also be identified in the Ticino, where the southern tail and some areas in the subarea centre disclose smaller cumulative losses due to bedload transport. Like the Ticino, the Grisons subarea shows the entire range of damage classes within its municipalities, from places with virtually no bedload damage to places with very high damage (>CHF 100 million). Compared to the other mountainous subareas (Prealps, Central Alps and Valais) the spatial damage pattern of these two subareas is considerably more heterogeneous. This is also reflected by the percentage of municipalities affected by bedload transport damage during the $40 \mathrm{yr}$ period (Table 1). Whereas many communities in the Prealps, Central Alps and Valais subareas have encountered bedload transport problems over the years $(>72 \%)$, the Grisons and Ticino subareas have a somewhat smaller percentage of affected communities $(<57 \%)$.

\subsubsection{Regional level}

The total damage costs due to natural hazard processes (as reported in the Swiss flood and landslide damage database) and damage costs caused by bedload transport only are represented in Fig. 4, aggregated for the seven subareas and the entire $40 \mathrm{yr}$ period. Total damage is highest for the Swiss Plateau subarea (ca. CHF 3000 million), closely followed by the Central Alps. Considerable total damage costs are also reported in the subareas Prealps, Ticino and Valais, whereas Jura and Grisons show noticeably lower values.

The cumulative damage costs solely induced by bedload transport processes are highest in the Central Alps (CHF 1310-1490 million). While in the Valais and Ticino subareas the upper estimates also lie above CHF 1000 million, they amount to roughly CHF 770 million in the Prealps and to about CHF 270 million in the Grisons. Combined, the mountainous subareas (nos. 3-7) make up more than $90 \%$ of the financial losses connected to bedload transport processes. As mentioned above (see also Fig. 3), problems related to bedload are less pronounced in the Swiss Plateau and Jura, where cumulative financial losses of only approximately CHF 240 and 25 million were reported, respectively.

For every municipality, we normalized bedload damage costs with population and divided the result by 40 to determine costs per person and year. We then averaged the data for every subarea and included the results in Table 1. They confirm the distribution of bedload damage costs at regional level, with values of more than $215 \mathrm{CHF} \mathrm{cap}^{-1} \mathrm{a}^{-1}$ for the Central Alps, Valais and Ticino subareas. Reflecting the quite low financial losses and moderate percentage of affected communities, costs per person and year amount to a comparatively low $26 \mathrm{CHF}_{\mathrm{Cap}}{ }^{-1} \mathrm{a}^{-1}$ in the Grisons subarea. For the Swiss Plateau and Jura, losses per person and year are even much lower $\left(<1.5 \mathrm{CHF} \mathrm{Cap}^{-1} \mathrm{a}^{-1}\right)$.

The resulting fractions of damage costs caused by bedload transport to total damage costs are highly variable between the different subareas (Fig. 4). While in the mountainous part of Switzerland values amount to 0.3 or higher for all subareas, the Swiss Plateau and Jura show very low fractions of less than 0.1 , as most of the total financial losses are caused by inundations along larger rivers and lakes. The fraction is by far highest for the distinctly Alpine Valais subarea (ca. 0.6), followed by the Central Alps and Ticino (slightly below 0.5 ). At about 0.3 , the Prealps subarea shows a slightly below average value compared to the Swiss mean. In summary, the subareas with an elevated fraction of bedload damage costs for the $40 \mathrm{yr}$ study period generally feature a considerable cumulative financial loss induced by bedload processes. The only exception to this norm is the Grisons subarea, which shows both quite low bedload and total damage costs resulting in an above-average ratio of approximately 0.4. 


\subsubsection{Geotechnical units}

On the basis of the geotechnical map of Switzerland and associated information on the mechanical weathering resistance (BFS GEOSTAT/BUWAL, unpublished data), we applied the six classes of the geotechnical weathering index defined by Rickenmann and Koschni (2010). In all subareas with the exception of Jura, loose quaternary deposits are one of the predominant lithological classes (see also Table 1). It covers around $40 \%$ of the area of Switzerland and approximately $83 \%$ of the total estimated bedload damage costs occurred on areas covered by this class. This can partly be explained by the fact that bedload damage occurs in settlements, along streets and rivers that are generally situated on alluvial deposits. Even in steep terrain in mountainous areas damage often results in the valley bottoms where goods and infrastructure are concentrated.

\subsection{Damage due to bedload processes during major natural hazard events}

Hilker et al. (2009) described in detail six major flood events registered in the damage database since 1972. We decided to resume the discussion to show how completely different the damage symptoms caused during major flood events can be, depending on the affected regions and the occurring processes. Similarly, the importance of bedload transport processes during such major events varies substantially. We added a recent event to the established list, the August 2007 flood event, because it stands in contrast to several of the other events. Table 3 includes a total of seven flood episodes and lists the total amount of financial loss for each event, the percentage of the estimated financial loss caused by bedload transport and the associated process uncertainty index.

The fraction of bedload transport damage for the individual events varies between approximately 0.04-0.06 (May 1999) and 0.86-0.92 (September 1993). These two extremes are exemplarily discussed below, together with the August 2007 event which yields a low fraction just somewhat above the fraction of the May 1999 event. Three major events (August 1987, October 2000, and August 2005) show fractions of bedload transport damage that roughly correspond to the value for the full investigation period (0.32-0.37). The event that occurred in August 1978 shows a very high percentage of bedload transport damage mainly due to floods in several rivers of the Ticino subarea that have caused excessive erosion, sediment transport and subsequent deposition.

\subsubsection{The 1993 Brig sediment disaster}

In September 1993, three days of persistent and extensive rainfall over the Valais and Ticino regions caused devastating damage mainly in the Upper Valais. By the afternoon of 24 September the discharge of the Saltina river along its al- luvial fan was elevated and had reached $70 \mathrm{~m}^{3} \mathrm{~s}^{-1}$. Subsequently, considerable amounts of sediment were transported into the zone of the Saltina bridge in the town of Brig. These had been mobilized upstream as soon as the discharge had reached a threshold value of $40-50 \mathrm{~m}^{3} \mathrm{~s}^{-1}$. At supply rates of about $1-1.5 \mathrm{ts}^{-1}$, the bedload material began accumulating below the bridge due to the locally reduced channel gradient. With increasing depth of the deposited sediment, the transport capacity of the Saltina river further decreased and the water level rose. Gradually, water started to hit the bridge and to flow off sideways, while water discharge in the channel below the bridge decreased, allowing for further deposition of material. The flow cross-section underneath the bridge was progressively filled up until it was totally clogged. Finally, large-scale flooding and overbank sedimentation in parts of the municipality of Brig-Glis occurred. It is obvious that bedload processes played a key role during this flood event, amplifying the financial losses excessively (Bezzola et al., 1994; Badoux and Rickenmann, 2008). Sadly, the event caused two fatalities. The area of the Brig train station and several streets were covered up with coarse and fine sediment up to $2 \mathrm{~m}$ deep. Massive damage occurred on hundreds of buildings, and many basements were completely filled up with material. Furthermore, infrastructure, facilities and numerous parked cars were destroyed. After the event approximately $30000 \mathrm{~m}^{3}$ of sediment had to be cleared. Brig-Glis was by far the municipality that suffered worst during the 24 September 1993 flood event (Röthlisberger, 1994). Total financial loss amounted to CHF 770 million, of which 86$92 \%$ were due to bedload transport. Thus, the event ranked fourth in terms of total damage, third in terms of bedload damage, and first as an event affecting a single community (Table 3).

\subsubsection{The May 1999 and August 2007 flood events}

In contrast, the large flood event that occurred in May 1999 (often subdivided in two different periods 11-15 and 2022 May; see BWG, 2000) hardly included any damage due to bedload transport processes. Snow melt in combination with rainfall led to an increase of lake and river levels, especially in the northern, less-mountainous areas of Switzerland. Damage was mostly generated through stagnant inundation on lake shores and flooding along some of the larger rivers, notably in densely settled areas such as the city of Berne (Aare river) and the city of Thun (Lake Thun). Total financial loss amounted to CHF 640 million. The subareas of the Swiss Plateau and the Prealps were severely affected. Some damage was also registered in the Central Alps (partly by landslides) and Jura along the Rhine river. As inundations occurred mainly because of very high lake levels and along low-gradient streams downstream of such lakes, bedload transport played a minor role in the reported damage processes. When the water moved back, flooded areas were often only covered by a thin layer of silt. Similarly, in August 
Table 3. The impact of bedload transport processes for damage costs during seven major flood events in Switzerland (since 1972).

\begin{tabular}{|c|c|c|c|c|c|c|}
\hline \multirow[t]{2}{*}{ Year } & \multirow[t]{2}{*}{ Date } & \multirow[t]{2}{*}{ Most affected subareas ${ }^{\mathrm{a}}$} & \multirow{2}{*}{$\begin{array}{c}\text { Total costs of } \\
\text { damage (rounded) } \\
\text { [million CHF] }\end{array}$} & \multicolumn{2}{|c|}{$\begin{array}{c}\text { Fraction bedload } \\
\text { damage/tot. damage }\end{array}$} & \multirow{2}{*}{$\begin{array}{l}\text { Process uncertainty } \\
\text { index }{ }^{\mathrm{b}} \\
{[-]}\end{array}$} \\
\hline & & & & $\begin{array}{c}\text { (lower est.) } \\
{[-]}\end{array}$ & $\begin{array}{c}\text { (upper est.) } \\
{[-]}\end{array}$ & \\
\hline 1978 & 7-8 August & $6(95 \%)$ & 1020 & 0.68 & 0.80 & 2.01 \\
\hline 1987 & 24-25 August & $4(69 \%), 6(16 \%), 5(15 \%)$ & 1140 & 0.34 & 0.42 & 2.23 \\
\hline 1993 & 24 September & $5(>99 \%)$ & 770 & 0.86 & 0.92 & 1.23 \\
\hline 1999 & $11-15 / 20-22$ Мау & $2(49 \%), 3(28 \%), 4(11 \%)$ & 640 & 0.04 & 0.06 & 2.08 \\
\hline 2000 & 14-15 October & $5(68 \%), 6(25 \%)$ & 730 & 0.34 & 0.38 & 1.63 \\
\hline 2005 & 21-22 August & $4(35 \%), 3(27 \%), 2(21 \%)$ & 3120 & 0.34 & 0.39 & 1.80 \\
\hline 2007 & 8-9 August & $2(44 \%), 1(39 \%), 4(13 \%)$ & 390 & 0.14 & 0.17 & 1.56 \\
\hline
\end{tabular}

${ }^{\text {a }}$ Subarea numbers according to Table 1 and Figs. 1 and 3; percentage relate to total financial loss in a given subarea.

$\mathrm{b}$ The process uncertainty index given here applies for all bedload damage estimations within the given major flood event (assessed using the upper damage estimates for weighting single database entries).

2007 long-lasting rainfall led to floods especially in the Jura and Swiss Plateau subareas, where the capacity of the regulated system of Lake Neuchâtel, Lake Bienne, Lake Morat and the lower-lying river Aare was considerably exceeded. Analogically to the May 1999 event, bedload processes were not important during August 2007 (Bezzola and Ruf, 2009). The only notable damage caused by bedload transport was reported in the municipality of Roche (canton Vaud), where a steep mountain stream deposited a considerable amount of sediment in the centre of the village.

\section{Discussion}

\subsection{Data quality}

For some events comprised in the Swiss flood and landslide damage database it is difficult to comprehend the exact course of event and thus to identify whether bedload transport deposition or erosion played a crucial role in the damage process or not. We have introduced a process uncertainty index ranging from 1 to 3 to provide a qualitative evaluation of the reliability of our data regarding the significance of bedload transport during an event. The mean process uncertainty index calculated for the bedload damage cost estimations per pentad varies between 1.27 (1992-1996), which is a very good score, and 2.27 (1972-1976), which has to be rated as a rather poor score, while the $40 \mathrm{yr}$ long-term average amounts to 1.78 (Fig. 5 and Table 2). Early pentads of our data set show higher process uncertainty indices than the later pentads, and overall it seems that the process uncertainty is decreasing with time. As a matter of fact, data acquisition and recording has improved in the Swiss flood and landslide damage database during the last $40 \mathrm{yr}$. First, the quality of the raw data (mainly newspaper articles) has increased notably. Due to an increasing public awareness of natural hazards, the completeness and accuracy of media coverage has improved over time, even for events that occur in remote parts of the country. However, regional variations in the quality of

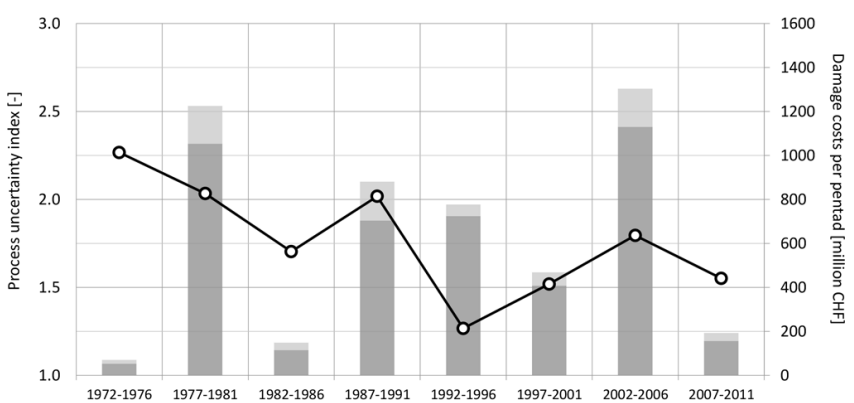

Fig. 5. Process uncertainty index for all bedload damage cost estimations per pentad (index describes data quality and was assessed using the upper damage estimates for weighting single database entries). The lower the index, the more reliable the information on the damage process. The grey bars in the background indicate the accumulated bedload damage costs per pentad (lower and upper estimates).

event reporting still persist (Hilker et al., 2009). Second, the workflow related to data acquisition and recording within the database has been considerably optimized over the last 15$20 \mathrm{yr}$. Today the whole process is handled digitally.

Furthermore, high process uncertainty indices were reported for the 1978 and 1987 major events (Table 3). During major events, a very large quantity of information is available which in the pre-digital era made it difficult to properly process all the data within the damage database. The September 1993 event represents an exception. Bedload transport processes played a key role back then and undoubtedly caused most of the financial losses recorded, which is reflected in a very low process uncertainty index (Table 3 ).

When averaged over months, the index appears to be lower during summer and autumn, when virtually the totality of financial losses due to bedload processes occur, than in winter and spring (with the exception of November; see Table 2). From November to March, the process uncertainty index actually shows poor to very poor results. We assume that this is because during these months the smaller and less 
Table 4. Bedload damage costs associated with a certain range of the process uncertainty index.

\begin{tabular}{|c|c|c|c|c|c|c|c|}
\hline \multirow[t]{2}{*}{$\begin{array}{l}\text { Class of process } \\
\text { uncertainty index }\end{array}$} & \multirow[t]{2}{*}{$\begin{array}{l}\text { Process uncertainty } \\
\text { index range }\end{array}$} & \multicolumn{2}{|c|}{$\begin{array}{l}\text { Bedload damage costs, } \\
\text { full period (upper est.) }\end{array}$} & \multicolumn{4}{|c|}{$\begin{array}{c}\text { Bedload damage costs, } \\
\text { decades }\end{array}$} \\
\hline & & [million CHF] & [\%] & $\begin{array}{r}(72-81) \\
{[\%]}\end{array}$ & $\begin{array}{r}(82-91) \\
{[\%]}\end{array}$ & $\begin{array}{r}(92-01) \\
{[\%]}\end{array}$ & $\begin{array}{r}(02-11) \\
{[\%]}\end{array}$ \\
\hline 1 & $1.00-1.49$ & 2366 & 46.7 & 18.2 & 41.8 & 78.4 & 48.4 \\
\hline 2 & $1.50-1.99$ & 317 & 6.3 & 3.3 & 4.7 & 4.1 & 11.8 \\
\hline 3 & $2.00-2.49$ & 1113 & 22.0 & 56.6 & 19.3 & 2.7 & 9.8 \\
\hline 4 & $2.50-3.00$ & 1269 & 25.0 & 21.9 & 34.3 & 14.8 & 29.9 \\
\hline Total & $1.00-3.00$ & 5065 & 100 & 100 & 100 & 100 & 100 \\
\hline
\end{tabular}

significant flood events are not often described accurately. Consequently, it is generally difficult to assess if bedload transport processes were really involved in the damage process or not.

Finally, we subdivided all database entries featuring bedload transport damage into four classes according to their process uncertainty index (Table 4). The width of a class amounts to 0.5 index points. Subsequently, bedload damage costs of all entries within a certain class were added up. It appears that nearly half of all damage costs that we attributed to bedload processes over the entire study period fall into the lowest class (indices $<1.5$ ), and thus show a very low to low process uncertainty. About as much financial loss (47\%) is ascribed to the two highest classes and is associated with medium to very high process uncertainty. In summary, more than $50 \%$ of our estimates show good credibility.

We have shown above that process uncertainty is decreasing within our study period (Fig. 5). This is confirmed by decadal data of bedload damage costs subdivided into uncertainty index classes (Table 4, columns 5-8). The percentage of financial losses associated with very low to medium process uncertainty (classes 1 and 2, indices $<2$ ) is low in the first decade $(21.5 \%)$ but increases strongly thereafter to reach $46.4 \%$ in the second decade. In the third and fourth decade the values lie above $60 \%$ (82.4 and $60.2 \%$, respectively) and suggest considerable improvements in the evaluation of damage data.

\subsection{Possible controls on bedload damage costs}

To investigate potential controls on damage costs caused by bedload deposition and sediment erosion, we plotted our estimates against several different parameters (Fig. 6). We also plotted the fraction of bedload damage costs to total damage costs (Fig. 7) as well as costs per capita (Fig. 8) against the same parameters. The damage data used in all graphs of Figs. 6 through 8 represent cumulative sums per subarea.

\subsubsection{Stream-channel gradient}

The first parameter applied to test the estimates of bedload transport damage is the mean channel gradient of streams within the entire subareas, or the community of interest. The gradients derived here thus do not correspond to the channel slope upstream of the damage location (cf. Sect. 2.4). Bedload transport damage costs display increasing values with increasing means (Fig. 6a) and standard deviations (Fig. 6b) of channel gradient. The correlation is stronger for the standard deviation $\left(R^{2}=0.65\right)$, suggesting that considerable gradient changes are more favourable to bedload damage occurrence than simply steep gradients. Correlations increase when channel gradient is plotted against the fraction of bedload damage to total damage (Fig. 7a and b). This indicates that, compared to the totality of damage induced by other natural hazard processes considered in the database, bedload transport damage has a stronger positive correlation with channel gradient, as would be expected from process considerations. For example, costly large-scale inundation is likely to be most important in flat lowland areas (e.g. along lake shores or large rivers in wide valley bottoms). Also, bedload damage shows a stronger link to channel gradient mean and standard deviation when normalized with population (Fig. 8a and b). Large agglomerations are generally situated in plains and population density tends to diminish in increasingly steep and precipitous terrain, explaining this observation.

The strength of channel gradient as a predictor for regional bedload damage costs is not surprising. Many of the simple prediction equations give bedload transport capacity as a function of channel slope and discharge (e.g. Rickenmann, 1991, 2001; Bathurst et al., 1987).

\subsubsection{Elevation}

When plotted against bedload damage costs, mean elevation (Fig. 6c) and standard deviation of elevation (Fig. 6d) yield similar results as stream gradient data, but with weaker correlation coefficients. Again, the standard deviation appears to be a better predictor of damage costs than the mean value. A high standard deviation of elevation suggests rough and rugged terrain with considerable slope variation, whereas high mean elevation could possibly also be observed on e.g. a high plateau. Areas reaching higher elevations obviously have a larger storage of loose material lying along steep 

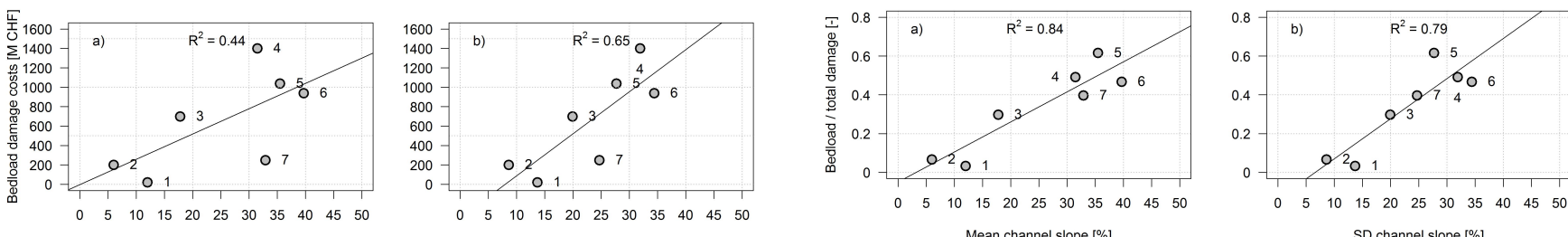

SD channel slope [\%]
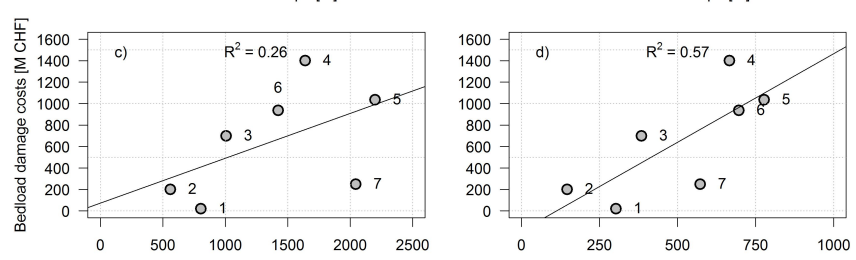

Mean channel slope $[\%]$

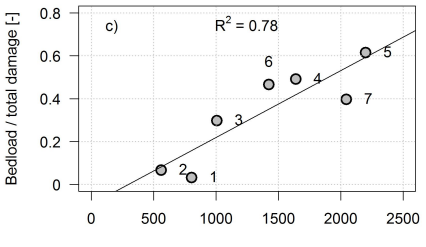

SD channel slope $[\%]$
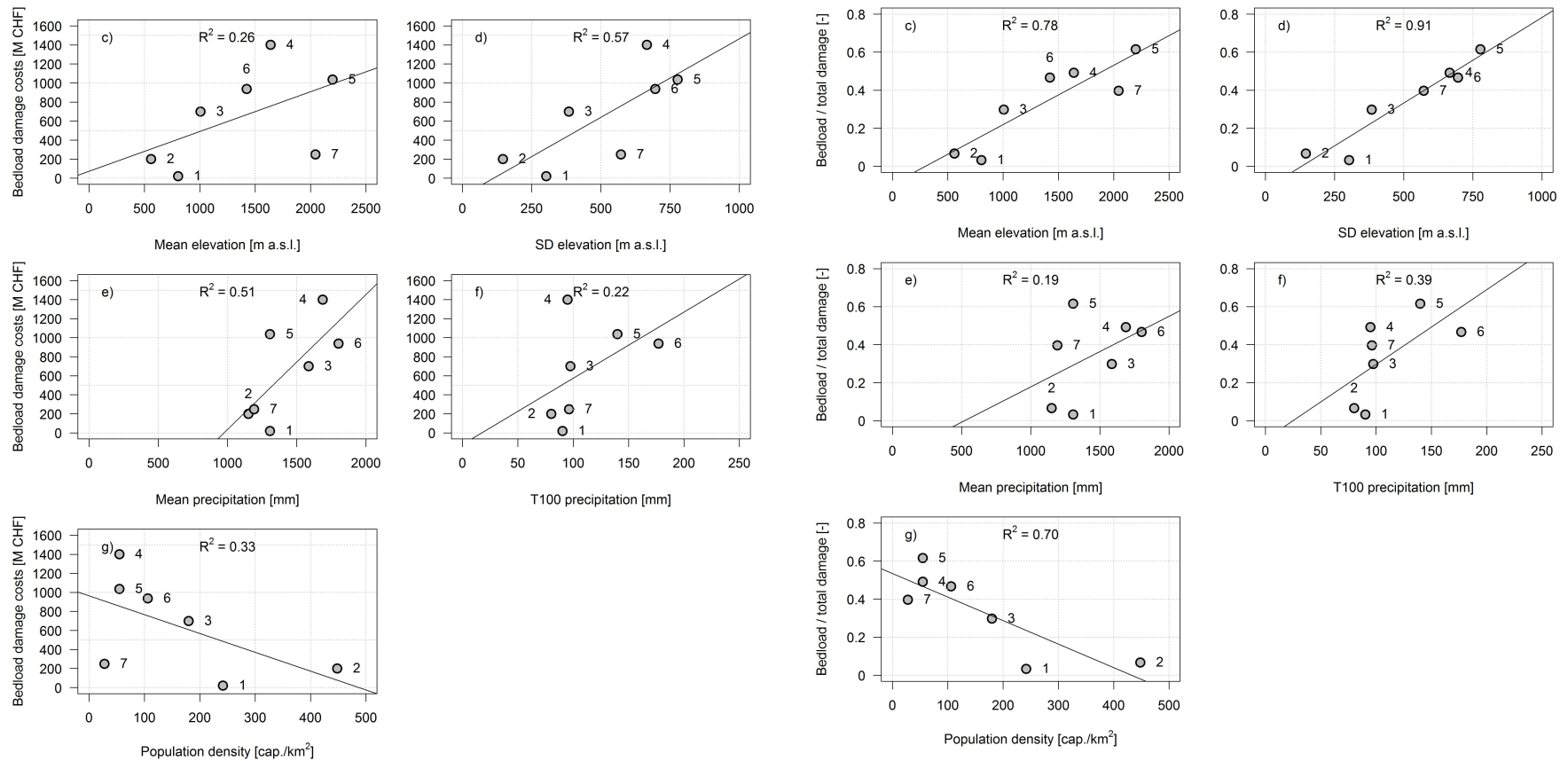

Fig. 6. Relation, for the seven different subareas, between the cumulative bedload damage costs and (a) the mean/(b) standard deviation of channel slope, (c) the mean/(d) standard deviation of elevation, (e) the mean annual precipitation, (f) the 1-day rainfall with a recurrence interval of $100 \mathrm{yr}$, and $(\mathrm{g})$ the population density. Note that the average of the lower and upper bedload damage cost estimates was applied. Numbers next to the data points denote subareas according to Table 1 and Fig. 1.

slopes until it is mobilized and transported downstream, potentially by bedload transport. A part of this material is supplied from glaciated areas or permafrost areas. Yet, it is probably not possible to identify whether sediment supply from glacial or permafrost origin influenced the amount of bedload damage costs within the subareas and over the investigation period. These areas represent only small fractions of the entire subareas and what might be traceable for small catchments is presumably not at larger scales. Moreover, steep streams draining highly glaciated areas might be better adjusted to carry intensive and highly variable sediment loads, leading to fewer damage incidents. It could also be expected that channels regularly transporting bedload are generally better protected by man-made protection structures. A full resolution of this question is, however, not possible in the context of this study.

Fig. 7. Relation, for the seven different subareas, between the fraction of bedload damage costs to total costs and (a) the mean/(b) standard deviation of channel slope, (c) the mean/(d) standard deviation of elevation, (e) the mean annual precipitation, (f) the 1-day rainfall with a recurrence interval of $100 \mathrm{yr}$, and $(\mathrm{g})$ the population density. Note that the average of the lower and upper estimates was applied to determine the fractions. Numbers next to the data points denote subareas according to Table 1 and Fig. 1.

Normalization of bedload damage with total damage (Fig. 7c and d) and with population (Fig. 8c and d) enhances the predictive quality of elevation data. Especially, the correlation of the normalized damage data with the standard deviation of elevation is very high, with coefficients of 0.91 (fraction of bedload damage to total damage) and 0.85 (bedload damage per person).

The correlation coefficients achieved by plotting the fraction of bedload damage with both gradient and elevation data (Fig. 7a-d) score in the range between 0.78 and 0.91 - higher than the coefficients obtained by simply plotting bedload damage costs with gradient and elevation data $\left(R^{2}\right.$ of $0.26-$ 0.65 , Fig. $6 a-d)$. The reason for this partly lies in the respective position of the Grisons data point (7). With rather low bedload damage costs for a mountainous subarea (Fig. 4), it plots well below the regression line in Fig. 6a-d. But because the total damage costs recorded for the Grisons subarea 

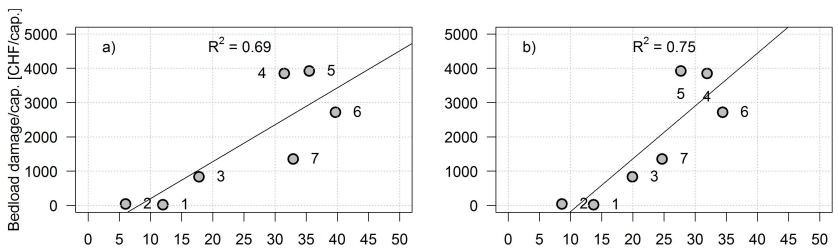

Mean channel slope $[\%]$
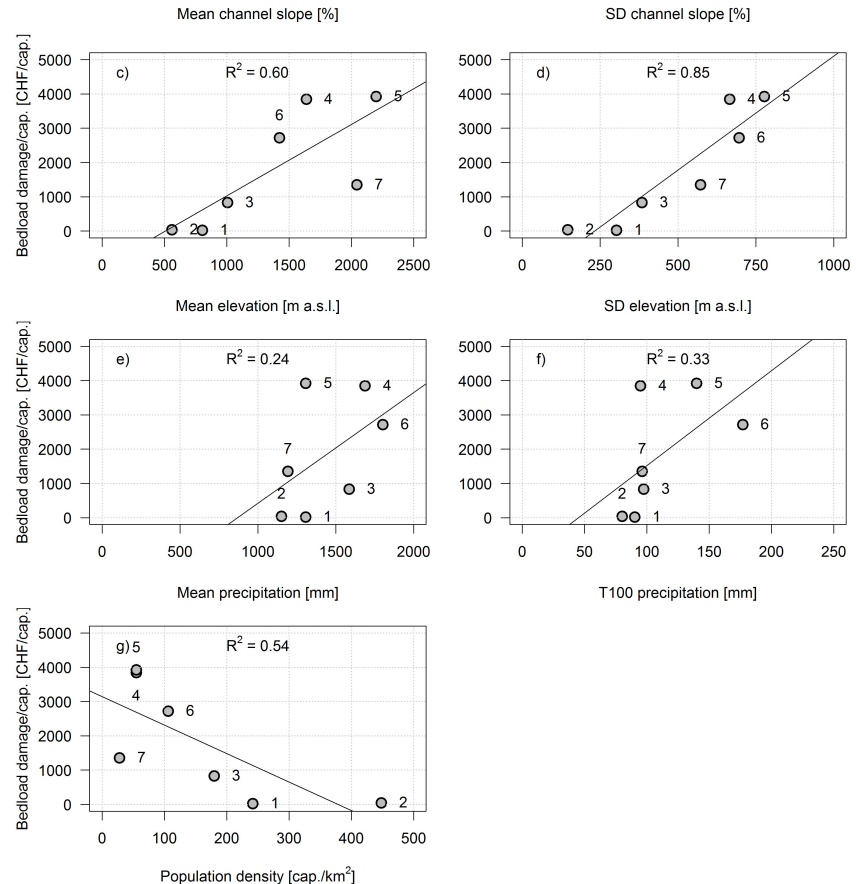

Fig. 8. Relation, for the seven different subareas, between the cumulative bedload damage costs per capita and (a) the mean/(b) standard deviation of channel slope, (c) the mean/(d) standard deviation of elevation, (e) the mean annual precipitation, (f) the 1-day rainfall with a recurrence interval of $100 \mathrm{yr}$, and (g) the population density. Note that the average of the lower and upper estimates was applied to determine the damage costs per capita. Numbers next to the data points denote subareas according to Table 1 and Fig. 1.

are comparatively low as well (Fig. 4), the resulting ratio of bedload damage to total damage plots in the very vicinity of the regression line in Fig. 7a-d. It is not fully understood why the Grisons subarea yields such low overall losses and bedload transport losses compared to other Alpine subareas. However, we assume that a combination of methodological shortcomings (a lower media echo regarding natural hazards leading to lower publication coverage as well as a comparatively short study duration) and possible differences in geomorphic channel capacity may be relevant.

\subsubsection{Precipitation}

Bedload damage costs and mean annual (subarea) precipitation have a fairly strong positive correlation (Fig. 6e), with $R^{2}$ of 0.51 . In general, higher precipitation leads to larger discharge values in steep streams. With available material in the catchments, high flows, in turn, can mobilize bedload, and under disadvantageous conditions overbank sedimentation or bed erosion occur, eventually causing damage costs. In contrast, the fraction of bedload transport damage to total damage is quite weakly correlated with subarea precipitation (Fig. 7e). It seems that the fraction increases with annual precipitation, but the high ratios observed for the Grisons and Valais subareas, associated with relatively low precipitation values (data points 5 and 7 in Fig. 7e), attenuate the relationship. When damage costs are normalized with subarea population (Fig. 8e), the positive correlation with precipitation is also very weak. Annual rainfall turns out to be a poor predictor for both the ratio of bedload damage costs and financial losses per person.

The $100 \mathrm{yr}$ values for daily precipitation determined for the subareas yield no further explanatory information for the bedload costs (Fig. 6f). The resulting positive correlation is weak, partly due to the high damage costs of the Central Alps subarea (data point 4) linked to a low $100 \mathrm{yr}$ rainfall. The main problem with the 1-day precipitation with a recurrence interval of $100 \mathrm{yr}$ is that the range of values for the seven subareas is tight. Five regions show a value that lies between 80 and $97 \mathrm{~mm}$, and only the Valais and the Grisons subareas have a substantially larger $100 \mathrm{yr}$ rainfall of 140 and $177 \mathrm{~mm}$, respectively. When looking at smaller areas (e.g. municipalities) the range of extreme rainfall values is expected to increase substantially (cf. Fig. 9). Normalization of bedload damage costs with total damage (Fig. 7f) and with population (Fig. 8f) does not considerably improve the predictive quality of the daily rainfall with a statistic recurrence period of $100 \mathrm{yr}$.

\subsubsection{Population density}

Bedload damage costs and (subarea) population density are negatively linked with each other, meaning that densely populated subareas tend to encounter less financial losses (Fig. 6g). The underlying correlation is not very strong though, mainly because of the moderate bedload damage costs in the most scarcely populated Grisons subarea (data point 7 in Fig. 6g). Because total damage costs reported in Grisons are low too (above and Fig. 4), its ratio of bedload damage to total damage lies within the range of ratios observed in other mountainous subareas. As a consequence, the correlation displayed in Fig. $7 \mathrm{~g}$ is considerably stronger $\left(R^{2}\right.$ of 0.70$)$ than the correlation of the non-normalized damage data with population density ( $R^{2}$ of 0.33 , Fig. $6 g$ ). Finally, when plotting bedload damage costs per person against population density, a fair correlation is achieved with a coefficient of 0.54 (Fig. 8g).

Our study suggests (at the regional level) that bedload damage costs decrease with increasing population density, which might seem contradictory because densely populated areas generally imply a concentration of goods and hence a higher damage potential. But in reality, very intense bedload 
transport processes eventually leading to considerable financial losses only occur in zones close to steep streams where population density is often widely restricted.

\subsubsection{Verification of controls using data at the municipal level}

To verify if our findings at the regional level (Figs. 6 through 8) also apply to the municipal level, we plotted normalized damage costs caused by bedload transport processes in Swiss communities against spatial mean values of channel slope, elevation, annual precipitation, $100 \mathrm{yr}$ precipitation and population density (Fig. 9a, c, e, f, and g, respectively) and against standard deviation values of channel slope and elevation (Fig. 9b and d, respectively). None of the correlations observed at the regional level apply at the municipal level (all $R^{2}<0.16$ ). Data points in all graphs show a very large scatter which does not allow any speculation on potential connections. This fact, however, is not very surprising, because (i) only a few municipalities have been seriously affected by a major meteorological event during the $40 \mathrm{yr}$ study period (Fig. 3), whereas the majority of municipalities only show very small damage costs per person and square kilometre; (ii) furthermore, many communities do not feature any steep mountain stream with a high damage potential due to bedload transport processes, even though they might be mountainous and show a high mean elevation and/or mean channel slope.

For all graphs of Fig. 9, municipal bedload damage costs per area and person were classified into logarithmically distributed bins in $x$ axis data. Binned means of normalized costs were then added to the graphs (black circles). On average, we find positive correlations of damage costs per capita per unit area with the mean and standard deviation of the channel bed slope, with mean and standard deviation of elevation and with both mean annual precipitation and $100 \mathrm{yr}$ rainfall. We find a negative correlation with population density. The observed correlations are as expected and can be explained by similar reasonings as are put forward above.

\subsection{Importance for bedload transport prediction}

As shown above, on average, fluvial bedload transport processes cause substantial damage costs in Switzerland. Some flood events that occurred in the last few decades were dominated by sediment erosion and bedload deposition and can be rated as proper sediment disasters. This stands in accordance with findings from Schmocker-Fackel and Naef (2010) reporting an accumulation of large events since the 1970s. We demonstrate that especially steep mountainous areas and areas characterized by abrupt changes in channel gradient are endangered by severe bedload transport processes.

Thus, the threat of large bedload transport events must not be underestimated in mountainous regions. Of course, this is no novelty for Alpine communities, but our long-term analysis of the impact of bedload transport processes for a na-
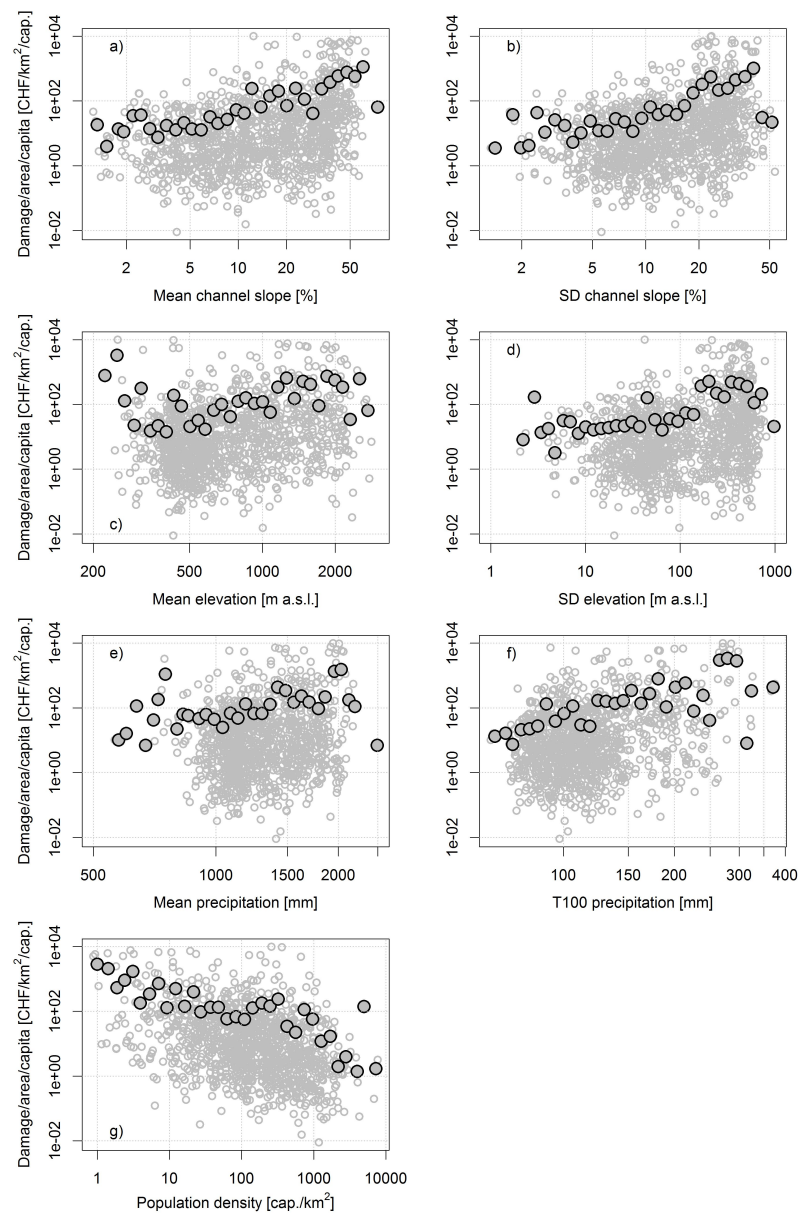

Fig. 9. Relation between municipal bedload damage costs normalized by area and population and (a) the mean/(b) standard deviation of channel slope, (c) the mean/(d) standard deviation of elevation, (e) the mean annual precipitation, (f) the 1-day rainfall with a recurrence interval of $100 \mathrm{yr}$, and ( $\mathrm{g}$ ) the population density. Grey circles represent the individual municipalities affected by bedload transport damage between 1972 and 2011. The black circles represent binned means.

tional economy represents a rare quantitative documentation of the problem. Our results emphasize the need for methods to predict sediment transport associated with large floods with reasonable accuracy. Such calculations are required and very useful for various flood safety activities, such as hazard assessment including the elaboration of hazard zoning maps, the design and construction of structural measures along streams and the planning of organizational measures in municipalities. However, approaches are needed that are easily applicable to a range of steep streams, not only in privileged parts of the world but also in regions with developing economies where highland inhabitants are more vulnerable to natural hazards and political-economic marginalization than populations elsewhere (Marston, 2008). Recently, several authors have responded to this requirement and have 
developed interesting approaches (e.g. Nitsche et al., 2011; Recking, 2010).

Albeit being too expensive and time consuming to be broadly applied in mountainous catchments, accurate bedload transport measurements are nonetheless of crucial importance to calibrate predictive equations (Rickenmann et al., 2012). Currently, cheap alternative monitoring technologies based on acoustics, vibrations, or impact measurements are being developed (Gray et al., 2010), but still need direct measurements using traps or retention basins for calibration.

The degree of safety to be achieved through protection measures (the protection objective) is widely defined by the damage potential in a given area. We assume that in Switzerland there is no substantial difference between the protection objectives along steep mountain streams prone to bedload transport and protection objectives in areas adjacent to large streams and lakes more prone to large-scale, rather static inundations. Hence, the ratio of bedload damage costs to total costs of 0.32-0.37 seems a representative value for Switzerland which is not likely to considerably increase or decrease in the near future. In comparison to other mountainous regions of the world, technical and organizational protection measures along steep mountain streams are quite well developed in Switzerland. Thus, we suspect that in other countries, especially less privileged and developed ones, the importance of bedload transport processes for overall natural hazard damage costs might be somewhat larger.

\section{Conclusions}

In this study, we assessed the contribution of bedload transport to total financial damage caused by natural hazards. For this purpose, we re-evaluated data of the Swiss flood and landslide damage database, which collects information on direct financial damage of naturally triggered floods, debris flows and landslides and covers the period from 1972 to 2011. Thousands of database entries were individually examined and it was assessed whether bedload transport erosion or deposition contributed to the occurred damage or not. In cases where it did, upper and lower limits of financial losses caused by or related to transport processes were estimated, and process uncertainty was considered.

In the $40 \mathrm{yr}$ study period, bedload transport processes have induced cumulative financial damage costs in Switzerland that lie between CHF 4.3 and 5.1 billion (lower and upper limits of our estimations). These losses, however, are highly variable both temporally and spatially. While in 2005 damage costs amounted to more than CHF 1140 million, 15 individual years have damage costs of less than CHF 10 million (mean of the lower and upper estimates). With mean annual financial losses of approximately CHF 118 million, the median is only about CHF 15 million. The seasonal distribution is highly variable because summer (June-August) is responsible for about $75 \%$ of the costs $(\sim 56 \%$ in August alone) and autumn (September-November) for about $23 \%$.
The spatial distribution of bedload damage costs reveals that municipalities with medium or high cumulative losses are concentrated in the mountainous part of Switzerland. While 15 communities show financial losses of CHF 50 million or more, a large number of communities all over Switzerland have not been exposed to any serious damage related to bedload transport, most of which are located in the lowlands. This pattern is confirmed when the cumulative bedload transport damage costs are aggregated for seven Swiss subareas: only about $5 \%$ of the costs occurred in the two non-Alpine subareas (Jura and Swiss Plateau), about $15 \%$ in the Prealps subarea and the principal part of the costs were generated in the four highly mountainous subareas (Central Alps, Valais, Ticino, and Grisons).

When put into relation to the overall damage costs caused by various natural hazard processes according to the Swiss flood and landslide damage database, we obtain a ratio of $0.32-0.37$ for the nationwide $40 \mathrm{yr}$ bedload damage data set. This fraction too, is variable in space and time. For single years, a low value of approximately 0.02 was determined for 1988 and a high value of 0.72 for 1978 , while the median value of all $40 \mathrm{yr}$ amounts to 0.18 (mean of lower and upper estimates applied for ratio calculation). The resulting fractions for the different subareas show a distinct pattern. Very low values of less than 0.1 are reported for the Jura and Swiss Plateau subareas. In contrast, the Prealps have a much higher ratio of approximately 0.3 , and in the Alpine subareas more than $40 \%$ of all damage costs are caused by bedload transport processes.

Potential controls on bedload damage costs, damage costs per person and the fraction of bedload costs to total costs were tested at the regional level. The strongest correlations resulted between (i) the fraction of bedload losses and mean value/standard deviation of channel gradient and elevation $\left(R^{2}>0.78\right)$, and (ii) the damage costs per person and the standard deviation of channel gradient and elevation ( $R^{2}$ of 0.75 and 0.85 , respectively). The absolute damage costs caused by bedload transport processes turned out to be more difficult to predict with the application of subarea characteristics, resulting in somewhat weaker correlations. Furthermore, mean annual precipitation, $100 \mathrm{yr}$ precipitation and population density are poor to moderate predictors for damage costs, costs per person and ratio of losses by bedload processes.

After more than a century of research, bedload transport processes are still not sufficiently understood. Our analysis quantitatively demonstrates the role of bedload transport as an important natural hazard and a considerable financial source of risk in Alpine environments. Thus, the study confirms the need for future structured research programmes on fluvial bedload transport in steep streams. Specifically, methods to predict sediment transport associated with large floods and capable of producing reasonably accurate information vital for flood mitigation measures and for the design of protective infrastructure are required. 


\section{Supplementary material related to this article is available online at \\ http://www.nat-hazards-earth-syst-sci.net/14/279/2014/ nhess-14-279-2014-supplement.pdf.}

Acknowledgements. We are very grateful to M. Sieber, who painstakingly screened more than 5000 database entries and provided preliminary estimates of bedload transport damage. We thank the Federal Office for the Environment FOEN - especially R. Loat and G. R. Bezzola - for the considerable contribution to the maintenance of the Swiss flood and landslide damage database. Furthermore, the authors would like to thank C. Hegg, D. Rickenmann, and B. McArdell for insightful discussions as well as M. Böckli and M. Zappa for support with data handling. All the WSL colleagues previously involved in the damage database project are also kindly acknowledged. Precipitation data were provided by MeteoSwiss (Federal Office of Meteorology and Climatology). J. Laronne, F. Comiti and an anonymous referee provided constructive and helpful comments that have improved the manuscript.

Edited by: P. Tarolli

Reviewed by: J. Laronne, F. Comiti, and one anonymous referee

\section{References}

Andres, N., Badoux, A., and Hegg, C.: Unwetterschäden in der Schweiz im Jahre 2012, Wasser Energie Luft, 105, 55-61, 2013 (in German).

Arnaud-Fassetta, G., Cossart, E., and Fort, M.: Hydro-geomorphic hazards and impact of man-made structures during the catastrophic flood of June 2000 in the Upper Guil catchment (Queyras, Southern French Alps), Geomorphology, 66, 41-67, doi:10.1016/j.geomorph.2004.03.014, 2005.

Badoux, A. and Rickenmann, D.: Berechnungen zum Geschiebetransport während der Hochwasser 1993 und 2000 im Wallis, Wasser Energie Luft, 100, 217-226, 2008 (in German).

Balog, J. D.: Flooding in Big Thompson River, Colorado, tributaries: controls on channel erosion and estimation of recurrence interval, Geology, 6, 200-204, doi:10.1130/00917613(1978)6<200:FIBTRC>2.0.CO;2, 1978

Bathurst, J. C., Graf, W. H., and Cao, H. H.: Bed load discharge equations for steep mountain rivers, in: Sediment Transport in Gravel-Bed Rivers, edited by: Thorne, C. R., Bathurst, J. C., and Hey, R. D., Wiley, Chichester, UK, 453-477, 1987.

Bezzola, G. R. and Hegg, C. (Eds.): Ereignisanalyse Hochwasser 2005, Teil 1 - Prozesse, Schäden und erste Einordnung, UmweltWissen Nr. 0707, Bundesamt für Umwelt BAFU \& Eidg. Forschungsanstalt WSL, Bern, Switzerland, 215 pp., 2007 (in German).

Bezzola, G. R. and Hegg, C. (Eds.): Ereignisanalyse Hochwasser 2005, Teil 2 - Analyse von Prozessen, Massnahmen und Gefahrengrundlagen, Umwelt-Wissen Nr. 0825, Bundesamt für Umwelt BAFU \& Eidg. Forschungsanstalt WSL, Bern, Switzerland, 429 pp., 2008 (in German).
Bezzola, G. R. and Ruf, W.: Ereignisanalyse Hochwasser August 2007, Umwelt-Wissen Nr. 0927, Bundesamt für Umwelt BAFU, Bern, Switzerland, 209 pp., 2009 (in German).

Bezzola, G. R., Abegg, J., and Jäggi, M. N. R.: Saltinabrücke BrigGlis (Rekonstruktion des Hochwassers vom 24. September 1993 in Brig-Glis), Schweizer Ingenieur und Architekt, 11, 165-169, 1994 (in German).

BWG: Hochwasser 1999, Analyse der Ereignisse, Studienbericht Nr. 10, Bundesamt für Wasser und Geologie BWG, Bern, 148 pp., 2000 (in German).

Costa, J. E.: Physical geomorphology of debris flows, in: Developments and Applications in Geomorphology, edited by: Costa, J. E. and Fleisher, P. J., Springer, New York, 268-317, 1984.

Einstein, H. A.: The bed-load function for sediment transportation in open channel flows, US Dept. Agric. Techn. Bull. No. 1026, Washington, D.C., 1950.

Frei, C. and Schär, C.: A precipitation climatology of the Alps from high-resolution rain-gauge observations, Int. J. Climatol., 18, 873-900, doi:10.1002/(SICI)10970088(19980630)18:8<873::AID-JOC255>3.0.CO;2-9, 1998.

Gray, J. R., Laronne, J. B., and Marr, J. D. G.: Bedload-surrogate Monitoring Technologies, US Geological Survey Scientific Investigations Report 2010-5091, US Geological Survey, Reston (VA), available at: http://pubs.usgs.gov/sir/2010/5091/, last access: 16 August 2013, 2010.

Hilker, N., Badoux, A., and Hegg, C.: The Swiss flood and landslide damage database 1972-2007, Nat. Hazards Earth Syst. Sci., 9, 913-925, doi:10.5194/nhess-9-913-2009, 2009.

Hunzinger, L. and Durrer, S.: Seitenerosion, in: Ereignisanalyse Hochwasser 2005, Teil 2 - Analyse von Prozessen, Massnahmen und Gefahrengrundlagen, edited by: Bezzola, G. R. and Hegg, C., Umwelt-Wissen, Nr. 0825, Bundesamt für Umwelt BAFU \& Eidg. Forschungsanstalt WSL, Bern, Switzerland, 125-136, 2008 (in German).

Jäggi, M. N. R., Nigg, U., and Teysseire, P.: Die Sedimentkatastrophe von Baltschieder, in: Internationales Symposion Interpraevent, 24-27 May 2004, Riva del Garda, Int Forschungsgesellschaft INTERPRAEVENT, 3(VII), 165-180, available at: http://www.interpraevent.at/palm-cms/upload_files/ Publikationen/Tagungsbeitraege/2004_3_VII-165.pdf, last access: 16 August 2013, 2004 (in German).

Krapesch, G., Hauer, C., and Habersack, H.: Scale orientated analysis of river width changes due to extreme flood hazards, Nat Hazards Earth Syst. Sci., 11, 2137-2147, doi:10.5194/nhess-112137-2011, 2011.

Lamb, M. P., Dietrich, W. E., and Venditti, J. G.: Is the critical Shields stress for incipient sediment motion dependent on channel-bed slope?, J. Geophys. Res., 113, F02008, doi:10.1029/2007JF000831, 2008.

Marston, R. A.: Land, life and environmental change in mountains, Ann. Assoc. Am. Geogr., 98, 507-520, 2008.

MunichRe: Topics Geo (Natural catastrophes 2011 - Analyses assessments, positions), Munich RE, Munich, Germany, 2012.

MunichRe: Topics Geo (Natural catastrophes 2012 - Analyses assessments, positions), Munich RE, Munich, Germany, 2013.

Nitsche, M., Rickenmann, D., Turowski, J. M., Badoux, A., and Kirchner, J. W.: Evaluation of bedload transport predictions using flow resistance equations to account for macro-roughness 
in steep mountain streams, Water Resour. Res., 47, W08513, doi:10.1029/2011WR010645, 2011.

Osterkamp, W. R., Heilman, P., and Lane, L. J.: Economic considerations of a continental sediment-monitoring program, Int. J. Sediment Res., 13, 12-24, 1998.

Recking, A.: A comparison between flume and field bed load transport data and consequences for surface-based bed load transport prediction, Water Resour. Res., 46, W03518, doi:10.1029/2009WR008007, 2010.

Rickenmann, D.: Hyperconcentrated flow and sediment transport at steep slopes, J. Hydraul. Eng.-ASCE, 117, 1419-1439, 1991.

Rickenmann, D.: Comparison of bed load transport in torrents and gravel bed streams, Water Resour. Res., 37, 3295-3305, 2001.

Rickenmann, D. and Koschni, A.: Sediment loads due to fluvial transport and debris flows during the 2005 flood events in Switzerland, Hydrol. Process., 24, 993-1007, doi:10.1002/hyp.7536, 2010.

Rickenmann, D., Turowski, J. M., Fritschi, B., Klaiber, A., and Ludwig, A.: Bedload transport measurements at the Erlenbach stream with geophones and automated basket samplers, Earth Surf. Proc. Land., 37, 1000-1011, doi:10.1002/esp.3225, 2012.

Röthlisberger, G.: Unwetterschäden in der Schweiz im Jahre 1993, Wasser Energie Luft, 86, 1-8, 1994 (in German).

Schmocker-Fackel, P. and Naef, F.: Changes in flood frequencies in Switzerland since 1500, Hydrol. Earth Syst. Sci., 14, 1581-1594, doi:10.5194/hess-14-1581-2010, 2010.

Totschnig, R., Sedlacek, W., and Fuchs, S.: A quantitative vulnerability function for fluvial sediment transport, Nat. Hazards, 58, 681-703, doi:10.1007/s11069-010-9623-5, 2011.
Vanoni, V. A. (Ed.): Sedimentation Engineering, American Society of Civil Engineers, New York, 1975.

Waananen, A. O., Harris, D. D., and Williams, R. C.: Floods of December 1964 and January 1965 in the far western states, Part 1. Description, US Geological Survey Water-Supply Paper 1866-A, 265 pp., available at: http://pubs.usgs.gov/wsp/1866a/report.pdf, last access: 16 August 2013, 1971.

Walther, P., Gräfe, H., Schmid, F., and Hegg, C.: Augusthochwasser 2002 in den Nebenflüssen der Oberen Elbe (Ereignisanalyse), in: Internationales Symposion Interpraevent, 24-27 May 2004, Riva del Garda, Int. Forschungsgesellschaft INTERPRAEVENT, 1, 133-144, http://www.interpraevent.at/palm-cms/upload_files/ Publikationen/Tagungsbeitraege/2004_1_I-133.pdf, last access: 16 August 2013, 2004 (in German).

White, S., García-Ruiz, J. M., Martí, C., Valero, B., Paz Errea, M., and Gómez-Villar, A.: The 1996 Biescas campsite disaster in the Central Spanish Pyrenees, and its temporal and spatial context, Hydrol. Process., 11, 1797-1812, 1997.

WSL Institute for Snow and Avalanche Research SLF: Avalanche bulletins and other products, Interpretation Guide (Edition 2012). WSL Institute for Snow and Avalanche Research SLF, Davos, available at: http://www.slf.ch/schneeinfo/zusatzinfos/ interpretationshilfe/interpretationshilfe_e.pdf, last access: 16 August 2013, 2012.

Wüest, M., Frei, C., Altenhoff, A., Hagen, M., Litschi, M., and Schär, C.: A gridded hourly precipitation dataset for Switzerland using rain-gauge analysis and radar-based disaggregation, Int. J. Climatol., 30, 1764-1775, doi:10.1002/joc.2025, 2010. 